\title{
Analysis Of Prerequisite IT Skills And Competencies Of Professional Accountants
}

\author{
Ana Novak ${ }^{1}$, Katarina Žager², Ivana Barišić3 \\ University of Zagreb, Faculty of Economics and Business
}

\begin{abstract}
:
Due to the role of information technology (IT) in today's business environment and the significant influence information technologies have on accounting operations, there is a growing need to continuous acquiring of IT knowledge and skills related to new and emerging IT. Given the current market demands for the accounting profession, the possession of IT skills and knowledge is imperative for both professional accountants in practice as well as accounting graduates. This paper investigates the skills that accounting graduates should develop through the analysis of a mixture of skills and competencies that are articulated by prominent professional accounting bodies along with the skills that employees deem important. In that context, special emphasis will be placed upon the analysis of the required IT skills and competencies. The paper aims to provide a detailed overview of the significant literature regarding prerequisite skills and competencies in ordering to identify expectations for future professional accountants that will serve as a basis for providing accounting education recommendations in that context. The results of the conducted analysis should provide useful information to higher education community as well as overall professional and scientific community.
\end{abstract}

Keywords: accounting; accounting information systems; accounting skills; information technology; information technology skills 